\title{
10. Towards a Post-Conflict Transition: Women and Artisanal Mining in the Democratic Republic of Congo
}

\author{
Rachel Perks
}

\section{Introduction}

This chapter ${ }^{1}$ represents a range of experiences by development actors, foreign donors, government and mining companies in response to the challenge of women's issues in the artisanal mining sector of the Democratic Republic of Congo (DRC). ${ }^{2}$ Although some statistics and trends are common across the country, this chapter speaks more specifically to the contexts of Katanga Province and Ituri District of Orientale Province. It does not in any way attempt to generalise what is a very diverse economic and social environment. It draws from Pact's ${ }^{3}$ work within a public-private partnership aimed at improving governance and livelihoods in the DRC mining sector. ${ }^{4}$

Artisanal and small-scale mining (ASM) in the DRC presents one of the greatest sources of economic opportunity for millions of Congolese citizens. It is estimated that two million people work as artisanal miners across the country, producing 90 per cent of the minerals exported (WB 2008; Hayes 2008). With

1 Sections of this chapter have since been used in Hayes and Perks (2011).

2 The learning found within this chapter would not be possible without the concerted efforts of actors to tackle the issues despite the obvious risks of working with such a volatile, illegal and opportunistic sector. In the DRC in particular, Anvil Mining Ltd, Anglo Gold Ashanti and United States Agency for International Development have consistently supported the work done in this domain by the international non-government organisation (NGO) called Pact. Other funding partners have included the International Finance Corporation, Tenke Fungurume Mining, Katanga Mining, and DCP/Nikanor. One cannot ignore the prime role played by Congolese women. In the Congo women face great personal security risks in speaking out against abuse, discrimination and exploitation. The courage to share their stories with Pact staff and researchers is sincerely recognised.

3 Pact Inc. is based in Washington D.C. and has been operating in the DRC since 2003. Pact's DRC country program focuses solely on the responsible management of natural resources which Pact regards as a fundamental requirement for sustaining peace and preventing further conflict. Pact works with private mining companies, local communities and the national government and is funded by a variety of partners.

4 See Appendix 10-1 for Pact's Gender ASM Partners in Katanga Province and Ituri District in Orientale Province. 
their dependents, it is estimated that the ASM sector provides economically for 18 per cent of the national population. Although this sector contributes to the livelihoods of such a large proportion of the population, it consistently exhibits some of the worst forms of labour, environmental and social practices found in the DRC today.

As with all recovering conflict countries, the DRC's peace and future for sustainable development rests largely on economic revitalisation. While humanitarian and development aid provides temporary relief to the most vulnerable population groups in an immediate transition period, long-term economic growth depends on outside investment and government regulation of its most profitable industries, with the mining sector being the most obvious.

However, whereas industrial mining will most likely constitute the backbone of the economy in the decades to follow, the real wealth and livelihood for individuals is presently found in the unregulated ASM sector. The transition period from ASM to large-scale industrial mining is wrought with potential conflicts and severe challenges as livelihood opportunities will be lost and access to resources will be restricted.

In the DRC, the current political, economic and social transition from war to peace continues to leave many root causes and drivers of the conflict unresolved. Within this framework of post-conflict transition, the security of communities remains fragile as the pillars of local governance, economic opportunity and social cohesion rebuild at an alarmingly slow pace. Within this void flourishes individual survivalism, impunity, and escapism-primarily by men-into alcohol and drugs.

Gender mainstreaming seeks to examine and redefine the roles attributed to men and women in a given social context. In the DRC's artisanal mining sector, as synonymous with the country as a whole, this is inherently linked to rebuilding the roles of men and women, and the values of each gender, following a period of conflict. While most advocacy and lobby groups focus on issues of revenue transparency, and the implementation of standards practiced by industrial companies, the deplorable conditions and discrimination facing artisanal miners remains largely overlooked, especially pertaining to women and young girls.

Women constitute between 40-50 per cent of the ASM workforce in Africa (Hinton et al. 2003). They constitute a significant economic force and often carry the burden of providing for whole households. In the DRC, as in most other African countries, women perform support service work to the industry and rarely engage in the physical act of mining. In particular, they also provide 
the majority of services at the mine sites and adjacent mine camps such as restaurants, markets, and small kiosks. Women work voluntarily and forcibly in the sex trade, often unprotected or under intimidation.

A concerted focus on transformation of the country's ASM sector is critical for ensuring overall stability in the DRC. In this process, gender considerations are imperative. Failure to address these conditions and enhance social capital will most likely result in further social instability, prevent the overall transition from war to peace, and ultimately have the potential to undermine mining companies' 'social license' to operate in such tenuous environments.

The work of Pact and its partners in addressing gender issues in ASM has led to important lessons that can help inform and improve global practice in this sector. Given the sheer number of women artisanal miners and their levels of poverty, overall sustainable transitions and reform of the ASM sector is not possible without targeted support towards gender challenges and issues. However, while gender-focused programming is essential, it must rest within a larger framework of ASM reform in order to ensure buy-in by other ASM actors. Pact's experience has shown that investment in women artisanal miners is more likely to increase broader social capital due to their role as sole income providers in many communities and their relationship to a more traditional and stable rural life. Women constitute a bridge between two very distinct and often isolated development contexts and their role in bringing ASM into the wider development agenda of the DRC is of great value.

Thus, gender issues should be at the forefront of social development initiatives in order to enhance social stability, whether through public-private partnerships, NGO and UN programs, or concession-based mining programs. To ensure this coherence, all actors - including mining companies - should align their development objectives and work within a commonly agreed framework to increase the potential for impact. This is important as the ASM sector has limited funding opportunities and actors in positions to effectively promote gender issues presently. In this regard, private-public partnerships can enhance benefits and limited resources and ensure complementarities.

\section{Background to Artisanal Mining in the DRC}

\section{Conflict Aftermath: Continued Importance of ASM}

The DRC is a country of great natural resources, mineral wealth and agricultural potential. But a debilitating colonial past and two civil wars have resulted in 30 years of neglect and consequently, at the time of writing: 70 per cent of its 
57.5 million inhabitants live below the poverty line; infant and child mortality rates have risen to 92 and 148 deaths per live births respectively; disease is endemic; infrastructure is virtually non-existent; general investor climate is marred by the still-unconcluded Mine Contract Review Process; and by fears of another war resurging in eastern Congo (WHO 2006).

Conflict in the DRC has typically been associated with the drive to gain and maintain control of natural resources. This relationship is not unique to the DRC, as demonstrated in Sierra Leone and Liberia, and is equally at the heart of persistent conflicts in places such as Sudan.

The DRC war from 1999-2003 claimed over five million lives, both directly and indirectly as a result of active fighting. In Ituri District (Orientale Province), it is estimated that 55000 people died and that another 200-300 000 suffered from severe human rights abuses, often at the hands of fellow villagers and family members (IRC 2004). At the time of writing, 1.5 million internally displaced persons are estimated nationwide with the third and fourth highest concentrations in Ituri District and Katanga Province; 185500 and 175815 respectively. While most conflict areas underwent relatively extensive and successful Disarmament, Demobilisation, and Reintegration (DDR) processes, large numbers of ex-combatants in parts of Ituri District, Maniema Province, and northern Katanga Province now work as artisanal miners. For example, it is estimated that up to ten per cent of artisanal gold diggers in select parts of Ituri District are ex-combatants. ${ }^{5}$

The transition from war to peace in the DRC is, and continues to be, slow, with a completed phase of DDR and humanitarian aid and what should naturally evolve to a more strategic development and social recovery agenda. Within this framework of post-conflict transition, the security of communities remains fragile at best, as the pillars of local governance, economic opportunity and social cohesion rebuild at an alarmingly slow pace, bedeviled by individual opportunism and a culture of impunity. Insecurity is largely economic in nature, as the majority is unable to find sustainable livelihoods and thus continue to find recourse in artisanal mining.

\section{Artisanal Mining at a Glance}

The profile of artisanal miners in the DRC varies from province to province. One encounters individuals who abandoned school at the age of nine and now at 41 continue to work as gold diggers in Orientale Province. One can also encounter law students from the University of Lubumbashi panning for surface ore during

5 Based on Pact baseline research into demobilised fighters on the Ashanti Goldfields Kilo concession, July 2008. 
school term breaks in the Kulu River of Kolwezi. The irony of artisanal mining in the DRC is that it exemplifies the greatest examples of Congolese ingenuity and entrepreneurship, and yet similarly reveals the greatest horrors of abuse, violence and exploitation.

As stated in the introduction, it is estimated that up to 2 million people work as artisanal miners across the country (WB 2008). With their dependents, it is estimated that the ASM sector provides economically for 18 per cent of the national population. Diamonds, copper, cobalt, gold, uranium and tantalum are the main resources extracted.

It is very important to view this statistic in global terms. Globally, large mines generate more than 95 per cent of the world's total mineral production. The industry employs an estimated 2.5 million people worldwide and is dominated by some 50 major mining and metals companies. Globally, ASM generates about 15 per cent of the world's minerals yet is a major source of income in about 30 countries around the world for an estimated 13 million people. Between 80 million and 100 million people are estimated to depend on small-scale mining for their livelihood with 52 million of them residing on the African continent.

The DRC is the reverse of this global situation. Approximately 90 per cent of minerals are produced by ASM and only 10 per cent by large-scale mining (Hayes 2008). This comparison serves to demonstrate the enormity of the transformation and the length of time that will be required for a peaceful formalisation of the mining sector.

Artisanal workers come from a variety of socio-economic backgrounds such as public security forces (current, demobilised and deserters), displaced farmers, and even skilled professionals. In the last decade, these individuals have become highly migratory, adapting to shifts in product demand across the country. Their temporary settlement in traditional communities can often have very negative social impacts including family break-up and polygamy, an increase in prostitution, abuse of alcohol and drugs, competition for-and destruction of - the communities' resources, and distortion of local market prices of basic goods due to their relatively higher daily income earned. Artisanal miners are frequently trapped in cycles of debt and poverty as a result of financial obligations to middlemen and women, known as 'negociants'.

In practice, artisanal miners' relationships with both traditional and local authorities are often governed by predatory taxation and bribery and their entry into indigenous sedentary villages is often viewed with mixed feelings by the local inhabitants. On the one hand, artisanal miners inject significant cash flow and attract services (such as kiosks, bars, and second-hand clothing 
stalls) otherwise unavailable in rural villages, while on the other hand, artisanal miners flout and attempt to coerce traditional and local government authority and impose a generalised social insecurity.

\section{Vulnerability and Gender Issues: Fragile State Context}

Pact's vision for its work in the DRC rests on re-establishing the security of communities wherein men and women play equally important, though perhaps different, roles in development. Security is not limited to physical protection but includes all aspects of life, most notably economic opportunity, health and wellbeing and community governance as expressed through social norms and traditional structures.

In any post-conflict fragile state, the period following an established cease-fire and peace process is critical as tangible 'peace' dividends must be felt by its citizens: people who have suffered prolonged and protracted conflicts tend to gauge the value of a peace period by what social, economic and political benefits they derive from it. Although this is often judged by basic social service delivery (such as education, health, water and roads), it also implies the security of individuals and their ability to perform daily livelihood functions without experiencing serious physical and/or psychological threats. For women, former combatants, and marginalised youth, it also implies the ability to actively participate in the economic and decision-making processes of their communities.

In the DRC, the current political, economic and social transition from war to peace continues to leave many of the root causes and drivers of the conflict unresolved. Within this framework of post-conflict transition, the security of communities remains fragile as the pillars of local governance, economic opportunity, and social cohesion re-build at an alarmingly slow pace. Within this void flourishes individual survivalism, impunity, and escapism-primarily by men-into alcohol and drugs. The vulnerability of women thus remains extremely high. In effect, women artisanal miners can be categorised as doubly 'at risk': they are rural women emerging from a war context and are additionally illegal workers living in precarious social, economic and environmental conditions.

This last aspect is important to consider. Societies learn to adapt during times of conflict with men often out fighting in the war and women home providing for families. Today one witnesses this continued adaptation in the migratory patterns of artisanal miners who leave wives and children in search of economic opportunities across the country. Rarely does money reach the family and women are in turn forced to seek livelihoods of their own. In concentrated artisanal environments, women will become labourers themselves or turn to supply businesses around the sites, including the sex trade. The vicious cycle of 
abandonment and resulting destruction of 'normal society' is witnessed when young females from as far as Kasai Province or North Katanga can be found working as prostitutes in artisanal areas along the southern border with Zambia.

Endemic to war and gender issues is also violence against women, which was used as an institutionalised tool of warfare in the eastern provinces of the DRC during the war. In artisanal mining communities, where high concentrations of ex-combatants reside, sexual and gender-based violence (SGBV) continues to be common practice.

As often with societies emerging from war and conflict, the traditional structures that once governed culture and social practice are either eroded or significantly diminished. Though Congolese women today would argue that the majority of past culture and social practice did not in fact promote respect and equal opportunity for women, they would agree that at least before the conflict, traditional structures existed for positive influence and change. Compounded with the usurpation of traditional authority and general disorder in ASM communities, gender re-definition becomes extremely complex as societies naturally evolve by grounding constructed roles and responsibilities in local leadership structures. The multi-ethnic composition of most ASM communities further complicates approaches to gender issues, as tribal values and practices vary significantly, and occur within the void of an overarching traditional governance structure.

For a society recovering from severe conflict, in order to restore reciprocity between genders as the means to 'normalising' social norms and hence community security, two complimentary avenues of approach are suggested. Firstly, the approach should address those ideas about what constitutes a man and, secondly, redress the powerlessness of women. In the first instance, and depending on the particular society's beliefs, attributes of maleness other than raw strength and power need to be brought to the fore. These positive attributes might include protection, fatherhood, responsibility and support. Secondly, women need to be empowered, to be recognised (not only by men, but by themselves) for the essential roles and attributes they bring in relation to men. Both of these avenues of approach need to be grounded in the material, economic parameters of their lives. In other words, men need to be reminded of other aspects of their manhood and given the opportunity to express these through work, the provision of economic support and protection of their partners. Equally so, women need to demonstrate the essentiality and importance of their contributions through work, the provision of economic support, and participation in decision-making. 


\section{The Development Entry Points}

Within the above theoretical framework, Pact has chosen the following entry points for addressing gender mainstreaming in ASM.

Women-focused interventions that include:

- Literacy and savings training.

- Alternative livelihoods to transition out of artisanal mining.

- Female social capital for advocacy and decision-making in communities.

- Sexual and gender-based violence.

Men-focused interventions that include:

- Literacy and savings training for men to emerge from cycles of debt.

- Awareness on domestic violence.

Community interventions to improve artisanal work conditions, household and community economic earnings, and individual wellbeing, including:

- Workers' rights regarding child care and health conditions.

- Transition economies out of artisanal mining into agriculture and small business development.

- Primary health care and HIV/AIDS in artisanal mining communities.

- Community mechanisms to monitor and address sexual and gender-based violence.

Such an approach works with both men and women, and the community at large. These strategies reduce potential backlash on women, position the gender argument within the wider community and look towards long-term economic and social solutions.

\section{Challenge for ASM within the Broader Development Agenda}

ASM is provided for under the current 2002 DRC Mining Code. However, government regulated artisanal zones are extremely limited, forcing the majority of artisanal mining to occur in a void of government oversight and support. This makes interventions by interested partners limited. International agencies and donors are hesitant in general to be seen working closely with the extractive industry sector in the DRC and even more so with ASM given its associated reputation with corruption, bribery, and abuse.

For example, at the time of writing, in Katanga Province only six development projects from private and public sources target ASM issues. Of these programs, 
none have a specific gender focus though women are beneficiaries of child education, health awareness, and economic alternatives activities. In Ituri District, there are only two projects that currently focus on ASM. Neither targets women directly.

Contributions by industrial companies are equally limited as companies shy away from intervening in a sector that is still largely illegal and exploitative. The most common strategy used is the offer of alternative employment. However, artisanal women, who are largely uneducated, rarely fulfill employment criteria for industrial recruitment as it often entails high-intensity manual labour or operating of machinery. As confessed most recently by a senior mine manager, affirmative action to recruit women is not easy as 'they just don't have the base qualifications'. Thus women rarely gain from transition opportunities due to their inability to physically respond to manual labour positions or due to their lower education background.

\section{Justification for 'Women in ASM' Development Focus}

If limited funds and interest exist for ASM sector reform in the DRC, what then becomes the case for a focus on women's interests in particular?

Firstly, women may constitute upwards of 50 per cent of the current ASM labour sector and carry greater economic burden and responsibility than their male counterparts. In some mining areas, women on average constitute up to 70 per cent of single ASM households with an average of six child dependents. This includes widowed, abandoned and divorced women as well as those with unemployed husbands. Yet as already outlined, they are often the least considered in ASM programming in the DRC.

Secondly, working with women artisanal miners often increases sustainability of economic livelihood alternatives and enhances social change as women are not as mobile as men when seeking ASM opportunities, and thus they generally remain rooted in their communities. They constitute a bridge to more traditional social life and structures, and thus increase the chances of influencing the broader dynamics for behaviour change.

Thirdly, in the experience of Pact staff and researchers, women are more likely to abandon mining and work on economic transition opportunities if given the chance. They are less reticent towards alternatives and do not make high demands for compensation. Though men in general have proven to be far more entrepreneurial when it comes to taking new business risks, female artisanal miners remain committed to an opportunity and save more from their earnings over time. 
However, as with any other attempt to address equity and equalisation of gender roles, programming focused solely on women can quickly alienate them from the broader society and make men even more resistant towards change. Especially concerning sexual violence against women, the roots are often found in male feelings of powerlessness and social marginalisation. By focusing on women alone, efforts could in fact produce violent backlashes and make women more insecure than before. Thus any efforts to address gender issues in the ASM sector need to be within a broader framework for change where all parties find their interests represented.

\section{Women and ASM: Katanga and Orientale Provinces}

The following discussion touches upon Pact's experience with partners across two distinct geographic areas of the DRC. At the time of writing, Katanga Province is undergoing an industrial mining renaissance, with companies mining primarily copper and cobalt. In the northeast of the country, Ituri District of Orientale Province is slowly recovering from the impact of conflict with a few major companies considering operations, mainly in the gold sector.

\section{Economic Empowerment and Livelihood Alternatives}

Women work in and around artisanal mines, most often as processors and transporters of raw materials. They also act as service providers to the mine in the areas of commerce, catering and, frequently, prostitution. The peripheral nature of these roles has significant impacts on the potential livelihoods for women, as they rarely participate in the core mining activity and thus do not have a voice in operational decision-making. In Katanga Province, examples do exist of women 'negociants', the middle person who sells raw ore to traders, but such examples are rare.

In 2007, Pact with support from the International Finance Corporation (IFC), USAID, and four major mining companies (Tenke Fungurume Mining, Anvil Mining Ltd, Katanga Mining and DCP/Nikanor) completed an eight-month research project into the artisanal mining sector of Kolwezi, Katanga Province. A socio-economic survey interviewed 255 artisanal women miners to ascertain levels of income, social circumstances, and barriers faced in the ASM sector.

The survey revealed that single, divorced or widowed women make up 36 per cent of the female population, having to care for six children on average. Thus, this group can be effectively classed as female-headed households. Such 
a large percentage of female-headed households in any given population is an indication of several underlying conditions. Firstly, it indicates by virtue of the absence of male heads that nuclear family norms have been disrupted, either through such avenues as poverty and loss of assets or through migration of males or through generalised breakdown of overall societal norms. ${ }^{6}$ Secondly, it indicates a greater dependency ratio of children to adults, with single women carrying a greater burden to provide for their children than standard nuclear joint-spouse households. Thirdly, it indicates diminished access to resources in these households, due to limited household assets such as land (normatively accessed through males) and unequal access to employment and fair wages by virtue of being women and subject to economic discrimination.

The number of these vulnerable female-headed households is augmented by a further 52 per cent of married women's households in which the spouses are unemployed and thus dependent on a single source of income. In effect, 70 per cent of all of the women surveyed were the sole income sources for their families.

In response to such staggering figures, Pact with Anvil Mining Ltd has been modeling economic transition alternatives with female artisanal miners in Kolwezi. The program combines literacy and savings programs with vocational training and technical accompaniment. Over the course of one year, 80 former artisanal women miners have successfully transitioned out of artisanal mining into other economic opportunities. In most cases, women are pursuing two income-generating activities due to the seasonal nature of agriculture, thus combining farming with small businesses in town such as bakeries and restaurants. Beyond the tangible economic and health benefits, women attest to a greater sense of self-worth and confidence provided by the literacy program.

Economic transition activities do present challenges, though easily overcome if recognised at the outset. Of greatest importance is ensuring income is available during the initial transition period as artisanal miners are used to earning income on a daily basis. When presented with business opportunities where initial income will not be generated, creative solutions to bridge the earning gap must be identified and supported.

6 There is one exception to this generalisation and that is when female heads are dependent on remittances from spouses who have migrated successfully in search of employment - this exception does not appear to be the case for Kolwezi given that it is itself is a magnet for labour migration. 


\section{Reproductive Health}

Health and safety is major area of concern in the ASM sector as a whole. Men and women alike suffer from a variety of respiratory illnesses, many chronic due to long-term exposure to highly mineralised ore bodies, or mercury used in gold recovery processing.

For women, the impact of these working conditions has generational consequences. In Kolwezi, alarming rates of stillbirths, miscarriages, and birth of deformed babies are documented by the Small-Scale Mining Technical Assistance and Training Service (SAESSCAM), the government body responsible, and Paraclisis Research Group at the University of Lubumbashi. These cases are most common with women exposed continuously to highly radioactive substances such as uranium, copper and cobalt. Out of 350 children surveyed in 2007 by Paraclisis Research suffering from respiratory problems, 41 per cent had parents who worked as artisanal miners and frequently accompanied their parents to the mine site. The ignorance regarding the health consequences of artisanal mining is high and necessitates concerted efforts in education awareness campaigns.

Further, across artisanal sites and camps, women have little exposure to health prevention measures. Women sex workers are frequently forced to engage in unprotected sex, increasing their chances of contracting sexually-transmitted diseases (STDs), and HIV/AIDS. In partnership with USAID, Pact has trained 20 women artisanal miners in basic health and reproductive education in Kawama, the Katanga Province's first official artisanal zone. This sensitisation created a demand from women in the market to sell condoms at their kiosks. Pact couples their rural women's health outreach programs with artisanal women working and living in adjacent communities.

\section{Sexual and Gender-Based Violence}

Perhaps the most troubling aspect of women working in the artisanal mines and camps is their exposure to a violent and volatile community dominated by men unattached to either family, traditional community or place. During his March 2008 DRC visit, the former UN Special Envoy for Aids in Africa, Stephen Lewis, remarked that, 'the DRC is by far the worst place in the world for women. The destruction of women is beyond the capacity of the mind to absorb.' Though most of the media and advocacy efforts focus on the problem of sexual and gender-based violence (SGBV) in eastern Congo, two recent surveys carried out by Pact reveal alarmingly high rates of SGBV in and around artisanal mining environments in Katanga Province and Ituri District. 
The research showed that reported SGBV fell into four categories: sexual assault and rape, prostitution, forced marriage (le mariage précoce) and domestic violence. Sexual assault and rape was further assigned to three kinds:

1. Predations against girls and women of all ages by individuals or groups of men, usually under the influence of alcohol or drugs and including police and military personnel.

2. Violent assault and rape of girls under the age of 11, mostly victims of local sorcery prescriptions to individual men for the acquisition of wealth and virility.

3. Gang rape of girls between the ages of 12 and older participating in parties, street revelries or other community social festivities.

This research corroborates initial data found in a UNICEF qualitative study ${ }^{7}$ on GBV against children in the artisanal mines of Katanga Province.

The presence of SGBV in such socially unbalanced circumstances as mining camps should not be surprising. Given the weakening of traditional village authority together with the overwhelming predominance of single men, coupled with the already inferior social position of local women, especially the younger women and girls, alongside the more worldly women providing services to the camps, the unmitigated vulnerability of women and children is exacerbated.

Sorcery, fetishes and superstitions also heavily influence violence against women in all social contexts of the DRC. In the ASM sector, sex with young virgins, often children as young as five, is encouraged by witch doctors as a means to secure wealth. In one month alone in 2008, Pact received reports of the rape of three children; two of which were between the ages of two and four years old. In one case, the child was left in the woods after having been raped and the local chief discovered a group of men attempting to burn her alive suspecting her to be a witch.

In select parts of Ituri District, increasing rates of SGBV are linked to artisanal mining, and according to local partners working in one highly dense artisanal mining town, Mongbwalu, male miners constitute the main perpetrators of SGBV incidences. ${ }^{8}$ In 2007 alone, 1289 SGBV cases were reported in Mongbwalu and its surrounding area, with less than 20 per cent addressed. This is in comparison to a total of 1881 cases reported for the entire Ituri District in 2007 by the UN coordination mechanism. ${ }^{9}$

7 The author attended the de-briefing at the UNICEF office in Lubumbashi where the consultants hired by UNICEF presented their findings. At the time of writing, the UNICEF report had not been released.

8 The Mongbwalu Stakeholder Forum has kept records since 2007.

9 Source: UN Office for the Coordination of Humanitarian Affairs SGBV Coordination, Bunia. January 2008. 
In Katanga Province, the vulnerability of women and children living within ASM communities is equally staggering. Here, as is common elsewhere, incidents of SGBV are consistently underreported, so that the figures in Table 10-1 are only indicative of a much larger problem. In fact, local professionals working in the sector estimate under-reporting as great as 80 per cent.

Table 10-1: Reported incidents of rape in Katanga Province, Jan-Mar 2008.

\begin{tabular}{cccc}
\hline January 2008 & February 2008 & March 2008 & Total \\
\hline 40 & 141 & 153 & 334 \\
$\begin{array}{c}\text { Only 4\% of health } \\
\text { centres reporting }\end{array}$ & $\begin{array}{c}\text { Only 25\% of health } \\
\text { centres reporting }\end{array}$ & $\begin{array}{c}\text { Only 30\% of health } \\
\text { centres reporting }\end{array}$ & $\begin{array}{c}\text { 28 centres reporting out } \\
\text { of } 67 \text { total health centres }\end{array}$ \\
\hline
\end{tabular}

Note: under-repoting error exists for all data. Source: UNFPA 2008.

However, male artisanal miners are not the sole perpetrators of SGBV in and around ASM areas. The presence of police and army officials on industrial mining concessions, and in ASM zones, also contributes to increased insecurity for women. In most cases, a family will settle a rape case with a public security officer for as little as a goat. ${ }^{10}$ Rarely are cases reported to the authorities and even more rarely do they make it through the judicial system.

General prevention and reduction of SGBV incidents requires a varied approach including treatment of victims, strengthening of judicial systems, redefinition of gender roles in communities, and economic and social re-integration for victims and their families. With mining companies and UN partners, Pact is piloting models of prevention and reduction of SGBV in both Katanga Province and Ituri District. These models build on current UN coordination mechanisms for reporting and addressing SGBV while introducing stronger economic and gender re-definition aspects. This includes literacy and savings programs to build positive male social capital, reduce indebtedness towards 'negociants' and traders, and allow for economic transition opportunities to facilitate family reunification and normalisation of social relations.

Also, the presence of social development projects in and around heavilypopulated ASM sites is slowly contributing to behaviour change, particularly around reporting of incidences. This is important as a first step to reducing SGBV, as silence and fear of victims and their families to speak out against these violations encourages on-going impunity of aggressors. Through Pact's women's literacy and savings program, WORTH, women are reporting incidents of rape and sexual violence more frequently. Through a monthly human rights and security meeting between the security heads of mining companies, private security companies, public security forces, the UN, and Pact, incidents of rape and intimidation are reported on concessions. In addition, mining companies

10 The average market price of a goat is between US $\$ 50-60$. 
have committed to train their public and private security agents in SGBV related laws and penalties in the DRC and establish SGBV monitoring and reporting mechanisms on their concessions.

\section{Children and Education}

A troubling impact of ASM practice relates to the children of women workers. A plethora of factors drive women to bring their children to the mine site on a daily basis, including the need to supplement family income, lack of affordable education facilities, and insufficient child care alternatives. It is not uncommon to find babies sleeping under trees in the shade, with older children assisting in mining activities such as sorting and washing. In Kolwezi, it is estimated that 23.7 per cent of child miners work with their mothers at site (Pact Inc. 2007).

Women cite school fees as a main component of household income supplemented by their ASM work. Free primary education is not universally provided for in the DRC and even in areas where it is, it is often over-subscribed and underresourced. Through a partnership with Solidarity Centre and Save the Children UK, and with funds by the US Department of Labor and Anvil Mining Ltd, Pact is working to improve education facilities and resources, staff training, and afterschool activities in ASM-vulnerable communities in Kolwezi and Mongbwalu.

\section{Leadership and Representation}

The DRC's regulatory environment and capacity are weak, and existing laws such as the Mining Code are not enforced effectively. A range of government actors perform specific roles and responsibilities within the ASM sector, though much confusion exists around actual field practice. The manipulation of these mandates is a continued source of frustration for artisanal miners that drives suspicion, discrimination and exploitation, and often leads to violent conflict at mine sites.

The first key government actor is the Small-scale Mining Technical Assistance and Training Service (SAESSCAM) that theoretically provides technical input and support to artisanal miners, including protection and safety. The second is the Division des Mines who provide for an inspector at the mine sites. The third are the authorities tasked with creating artisanal mining zones and issuing cards for artisanal mining, trade and transport. Finally, the state is a buyer, through government bodies such as Gécamines (Katanga Province), MIBA (Kasai Orientale Province) and OKIMO (Orientale Province). However, given the lack of specific artisanal zones established and functioning in most parts of the country, 
the majority of these government bodies is entangled in webs of predation and exploitation, and is often highly distrusted by the very people they are meant to protect and represent.

Cooperatives should logically emerge to fill the gap in veritable representation of interests. To date in the DRC, very few cooperative or association structures do in reality perform such a role. Rather most are synonymous with high 'membership fees', that is taxes and few benefits. At best, these structures pay for ad hoc requests such as hospital bills and funerals. None of the above structures have specific gender policies. It is one of the most serious gaps the ASM sector faces for ensuring effective representation of women's issues.

\section{Moving Forward}

Artisanal mining will remain an important economic recourse in the coming years for thousands of individuals across the DRC. In fact, at the time of writing, it is anticipated that ASM may even increase as a result of several factors, including:

- liberalisation of the ASM sector in certain Provinces by government, such as in Orientale Province;

- continued instability in eastern Congo that fuels access to resources, and forces displaced persons to seek economic livelihoods outside their home areas;

- limited economic alternatives following industrial consolidation of mining concessions;

- on-going high demand for mineral resources by countries such as China, India and Russia; and

- a current global economic recession that has halted the majority of largescale mining projects in the DRC.

However, as this chapter demonstrates, the challenges facing the sector are great, let alone those that are gender specific. How then to build on the few lessons that do exist?

\section{Overcoming Challenges: Lessons and Achievements}

As previously stated, Pact has been working with a range of development actors, foreign donors, mining companies, and government to respond to the challenge of gender issues in the ASM sector of the DRC. This has formed part of broader efforts to increase understanding of ASM as an integral part of the broader 
development agenda for the DRC. The result has been increased collaboration between stakeholders, leading to a range of achievements and lessons learnt, including:

- Securing a policy framework for coordinated action and investment: SAESSCAM, with technical support from Pact, has proposed an ASM framework for the DRC to encompass all potential partners and funding sources over the coming five years. Gender mainstreaming is an integral part of the framework.

- Lobbying the Government and UN agencies to respond to specific women's sectoral challenges that cut across ASM and rural populations: HIV/AIDS and SGBV are two examples where Pact places great emphasis on integrating women artisanal miners into regular development programming.

- Establishing public-private partnerships that respond to both global development objectives and standards, and that are in line with the national development plan of the DRC Government: Whereas companies may not wish to fund ASM reform, public funds to support initiatives within a broader extractive industries public-private partnership is possible and has proven to work. Through USAID funding, four industrial companies in the DRC have benefited from select ASM initiatives by Pact and partners.

- Creating small pilot opportunities for collaboration with UN agencies and other development organisations: The Katanga Provincial Ministry of Mines is workorking in collaboration with UN Agencies and Pact to establish its first artisanal zone in Kawama. To date, a joint UN-Pact mission established baseline needs and statistics, and ongoing technical support is provided to the Ministry. A strong component of this support is to improve access to health and reproductive services for women artisanal miners, including education and testing facilities through local clinics.

- Integrating artisanal populations into community development projects if in the same operational area as a publicly-funded development program: Pact includes artisanal women into their literacy and savings' programs for rural women in addition to their education work with women on HIV/AIDS. 


\section{Appendix 10-1: Pact's Gender ASM Partners in Katanga Province and Ituri District in Orientale Province.}

\begin{tabular}{|c|c|c|}
\hline ASM partner & Sector & Location \\
\hline \multicolumn{3}{|c|}{ DRC Government } \\
\hline Ministry of Mines & Artisanal zones & Katanga Province \\
\hline SAESSCAM & $\begin{array}{l}\text { National framework for ASM, economic } \\
\text { transition }\end{array}$ & $\begin{array}{l}\text { Kinshasa and Katanga } \\
\text { Province }\end{array}$ \\
\hline \multicolumn{3}{|l|}{ Donors } \\
\hline USAID & SGBV, economic transition, HIV/AIDS & $\begin{array}{l}\text { Katanga Province and } \\
\text { Ituri District }\end{array}$ \\
\hline $\begin{array}{l}\text { US Department } \\
\text { of Labor }\end{array}$ & Child miners education & $\begin{array}{l}\text { Katanga Province and } \\
\text { Ituri District }\end{array}$ \\
\hline IFC & Research into ASM & Katanga Province \\
\hline \multicolumn{3}{|l|}{ UN agencies } \\
\hline ILO & Labor practice, representation and leadership & Katanga Province \\
\hline UNFPA & $\begin{array}{l}\text { SGBV, HIV/AIDS, STDS, Health and } \\
\text { reproduction }\end{array}$ & $\begin{array}{l}\text { Katanga Province and } \\
\text { Ituri District }\end{array}$ \\
\hline WHO & HIV/AIDS, STDS, Health and reproduction & Katanga Province \\
\hline Unicef & SGBV against child artisanal miners & Katanga Province \\
\hline UNDP & Economic transition & Katanga Province \\
\hline \multicolumn{3}{|c|}{ International NGOs } \\
\hline Pact & $\begin{array}{l}\text { SGBV, economic transition, leadership, } \\
\text { WORTH, and HIV/AIDS }\end{array}$ & $\begin{array}{l}\text { Katanga Province and } \\
\text { Ituri District }\end{array}$ \\
\hline $\begin{array}{l}\text { Save the Children } \\
\text { UK }\end{array}$ & $\begin{array}{l}\text { Prevention of child miners through education } \\
\text { and support to artisanal mothers }\end{array}$ & $\begin{array}{l}\text { Katanga Province and } \\
\text { Ituri District }\end{array}$ \\
\hline Solidarity Centre & $\begin{array}{l}\text { Prevention of child miners through education } \\
\text { and support to artisanal mothers }\end{array}$ & $\begin{array}{l}\text { Katanga Province and } \\
\text { Ituri District }\end{array}$ \\
\hline Groupe One & $\begin{array}{l}\text { Prevention of child miners through education and } \\
\text { support to artisanal mothers }\end{array}$ & Katanga Province \\
\hline \multicolumn{3}{|c|}{ National NGOs, universities, local associations and networks } \\
\hline $\begin{array}{l}\text { University of } \\
\text { Lubumbashi }\end{array}$ & Health and safety of women & Katanga Province \\
\hline $\begin{array}{l}\text { Réseau Action } \\
\text { Femme }\end{array}$ & SGBV & Katanga Province \\
\hline WORTH & $\begin{array}{l}\text { SGBV, savings and microcredit and small } \\
\text { business }\end{array}$ & $\begin{array}{l}\text { Katanga Province and } \\
\text { Ituri District }\end{array}$ \\
\hline \multicolumn{3}{|c|}{ Mining Companies } \\
\hline Anvil Mining Ltd & SGBV and economic transition & Katanga Province \\
\hline $\begin{array}{l}\text { Anglo Gold } \\
\text { Ashanti }\end{array}$ & SGBV, economic transition and employment & Ituri District \\
\hline
\end{tabular}




\section{References}

HHI (Harvard Humanitarian Initiative), 2009. 'Characterizing Sexual Violence in the Democratic Republic of the Congo. Profiles of Violence, Community Responses, and Implications for the Protection of Women.' Final Report for the Open Society Institute. Viewed 20 January 2011 at http://globalsolutions. org/files/public/documents/GBV_final-report-for-the-open-societyinstitute-1.pdf

Hayes, K., 2008. 'The Economics of Artisanal Mining in Africa.' Unpublished Pact Inc. Report. Viewed 9 September 2010 at http://empoweringcommunities. anu.edu.au/documents/Perks\%20paper\%20\&\%20cover\%20page.pdf

Hayes, K. and R. Perks, 2011. 'Women in the Artisanal and Small-Scale Mining Sector of the Democratic Republic of the Congo.' In S.A. Rustad and P. Lujala (eds), High-Value Natural Resources and Post-Conflict Peacebuilding. Earth Scan Publications.

Hinton, J., M. Veiga and C. Beinhoff, 2003. 'Women and Artisanal Mining: Gender Roles and the Road Ahead.' In G. Hilson (ed.), The Socio-Economic Impacts of Artisanal and Small-Scale Mining in Developing Countries. Netherlands: Swets Publishers.

ICRC (International Committee of the Red Cross), 2004. 'ICRC Annual Report 2004: Democratic Republic of the Congo.' Viewed 9 September 2010 at http:// www.unhcr.org/refworld/docid/46938ffc0.html

Pact Inc., 2007. 'Economic Development and Governance Transition Strategy for Kolwezi, Katanga Province.' DRC: Pact Inc.

UNFPA, 2008. 'Rapport des Nouveaux Cas des Violences Sexuelles Survenus au Katanga au Cours du Premier Trimestre, Mars 2008.' Initiative Conjointe de lutte contre les violences sexuelles faites aux femmes, aux jeunes, aus enfants et aux homes en RDC. [Report of new cases of sexual violence surveyed in Katanga during the First Quarter, March 2008, UNFPA: Joint Initiative to combat sexual violence against women, young people, children and domestic violence in the DRC.]

World Bank, 2008. 'Democratic Republic of Congo Growth with Governance in the Mining Sector.' Report No. 43402-ZR, Oil/Gas, Mining and Chemicals Department, AFCC2, Africa Region. Washington: The World Bank.

WHO (World Health Organization), 2006. Working Together for Health: The World Health Report 2006. Geneva: World Health Organization. 